\title{
Delistings of secondary listings: price and volume effects
}

\author{
Matthias Pfister • Rico von Wyss
}

Published online: 12 October 2010

(C) Swiss Society for Financial Market Research 2010

\begin{abstract}
Despite their growing importance in recent years, delistings of secondary listings have received very little attention. This article investigates whether a delisting is accompanied by any price or volume effects on the company's primary exchange. We apply a standard event study methodology to analyze these effects. The total sample consists of 255 companies that either delisted from the SIX Swiss Exchange, the Sponsored Segment of the SIX, Deutsche Börse, or the Tokyo Stock Exchange. The results show no significant price effects, either around the announcement or around the effective delisting. Furthermore, the results vary considerably between subsamples. Prices tend to decline around announcement; however, the effect is not permanent. The effective delisting is preceded by declining prices, whereas the event itself has no influence. Overall, this initial decline appears to be permanent. In general, volumes seem to rise around the announcement as well as around the date of the delisting.
\end{abstract}

Keywords Event study $\cdot$ Secondary listings $\cdot$ Delisting

JEL Classification $\mathrm{G} 12 \cdot \mathrm{G} 14 \cdot \mathrm{G} 39$

\section{Introduction}

Globalization and technological progress have led to a steady change in the structure of international equity markets. Companies acting at a global level are able to align

\footnotetext{
M. Pfister

Investment Banking Division, Morgan Stanley, Bahnhofstrasse 92, 8021 Zurich, Switzerland e-mail: matthias.pfister@alumni.unisg.ch

R. von Wyss ( $\square)$

Swiss Institute of Banking and Finance, University of St. Gallen, Rosenbergstrasse 52, 9000

St. Gallen, Switzerland

e-mail: rico@vonwyss.ch
} 
their international operations with a corresponding shareholder base by listing their shares on several exchanges simultaneously. During the 1980s and 1990s, a great number of companies cross-listed their stocks internationally. According to Das et al. (2004), the number of foreign companies listed on the eight major capital markets more than doubled between 1986 and 1997 and amounted to 3,768 in 1997. This trend has reversed in recent years. In particular, Asian and European stock exchanges have experienced delistings of foreign companies, while US capital markets continued to be attractive for foreign companies. At the global level, the share of listings of companies on foreign markets declined from $13.4 \%$ to $7.0 \%$ by the end of 2007 according to WFE (2008). It remains an open question whether the trend to cancel secondary listing is connected to the trend toward greater strategic focus by firms as documented, for example, in Basu (2010).

Theoretical considerations suggest that a dual listing increases the firm value and the stock's liquidity, whereas a delisting is expected to have the opposite effect. However, as the literature overviews in Karolyi $(1998,2006)$ show, prior research finds little evidence of a permanent increase in firm values from a cross-listing. Most studies show positive prelisting returns followed by negative post-listing returns, which eventually return the stock price to its initial level. On the other hand, studies on delistings mostly confirm theory and show a decline in firm value. Studies focusing on liquidity found, in general, higher liquidity following a cross-listing, with total trading volume typically increasing. Results of studies on domestic trading volume are ambiguous.

The vast majority of research on the effects of cross-listings analyzes reactions to listings; delistings receive considerably less attention. Moreover, due to the unavailability of data, liquidity effects have been investigated much more recently and to a much smaller extent than price effects. Since most of the studies focus on a variety of liquidity measures (most often bid-ask spreads), studies on trading volume are even rarer.

Merjos (1963) examines the effects of delistings using a sample of 58 firms delisting from NYSE or AMEX to the US OTC market in 1961 and 1962. 47 out of the 58 firms underperform the market in the periods immediately prior to and following the delisting. The last quoted price on NYSE or AMEX was considerably higher than the first available OTC price, which suggests adverse effects of delistings. On average, the companies lost $17 \%$ of their value. Sanger and Peterson (1990) conduct a comprehensive landmark study of delistings from either AMEX or NYSE in the period between 1963 and 1985 (out of the 520 stocks, 370 did not resume trading on any exchange). The results show a negative abnormal return of $8.5 \%$ on the announcement day (of the 100 firms that had announcements before the delisting). The share price in the post-delisting period does not exhibit an unusual pattern. The same study shows that the delistings are accompanied by a decrease in liquidity-measured by bid-ask spreads and trading volume.

Almost all research on delisting focuses on companies leaving their domestic exchange. Research on delistings of cross-listings in an international context is still in its infancy. Liu (2004) studies a sample of 103 companies from 20 different countries that involuntarily delisted from one of the three major US exchanges in the period from 1990 to 2003 . The results show a significant drop of $4.5 \%$ in share price on the 
announcement day, which appears to be a permanent decline. Liu (2004) was not able to relate this decline to changes in liquidity, since a long-term liquidity drop could not be found. At the same time, Das et al. (2004) investigated voluntary delisting of 45 US firms from the Tokyo Stock Exchange (TSE) between 1977 and 1997. This study finds negative abnormal returns around the announcement date $(-6.0 \%$ over a 51 -day event window) and around the actual delisting ( $-4.1 \%$ over a 51-day event window) as well as an average $30.6 \%$ increase in trading volume and an increase in bid-ask spreads on the domestic exchange. Ureche-Rangau and Carugati (2008) study voluntary delistings of 49 companies from the TSE between 1994 and 2005 using a multimethod approach including not only quantitative data but also qualitative information from a worldwide sample. Their full sample shows no statistically significant positive or negative returns around the announcement date. Results of the qualitative study show that the market reaction heavily depends on the content of the delisting announcement.

The aim of this article is to examine the impact of delistings of secondary listings on the share price as well as on the trading volume of a company's shares on its primary market (i.e., its domestic market). It investigates the effects around the announcement of the delisting as well as around the actual delisting. The analysis is focused on three major equity markets: the SIX Swiss Exchange (SIX) (1998-2008), Deutsche Börse (2001-2008), and TSE (1997-2008). Furthermore, companies trading in the SIX Sponsored Segment at the time of its cancellation in November 2008 are included. Trading in the Sponsored Segment shares many similarities with a secondary listing on SIX.

This paper is different from earlier research in that it analyzes and compares the effects of delistings from multiple exchanges and, therefore, the findings are based on a larger than usual sample. Furthermore, the sample is not confined to companies from just one country. The paper is more comprehensive than earlier research that predominantly focused on either price or volume effects either around the announcement or around the effective delisting. An extensive study focusing on both effects around both events simultaneously has never been conducted. In particular, volume effects resulting from delistings have not received much attention in earlier research.

The structure of this article is as follows. Section 2 provides a theoretical background and contrasts advantages and disadvantages of international cross-listings. The remainder of the paper empirically analyzes the effects of delistings. Section 3 outlines the rationale of the market selection and describes the data set. Section 4 briefly explains the event study methodology with the corresponding test statistics. Section 5 presents and analyzes the results of the empirical study. Section 6 concludes.

\section{Advantages and disadvantages of cross-listings}

\subsection{Advantages of cross-listings}

A secondary listing enables companies to raise new funds and opens access to a new market that serves as a basis for future equity or debt issues. Companies often expect 
higher share prices upon the announcement of a cross-listing, which allows them to raise more capital according to Hannich et al. (2005). Doidge et al. (2004) stress the access to more liquid and deeper capital markets that enables companies to raise funds at a lower cost. The access to several markets helps a company diversify its funding risk and avoid the problem of equity issues too big to be absorbed by the domestic market alone. In addition, according to Löwe (1998), the domestic market could be subject to local structural changes or cyclical developments.

As stated in Mittoo (1992) and King and Mittoo (2007), managers often cite improvement in trading liquidity as an important criterion for cross-listings. Higher liquidity leads to lower capital costs and a higher valuation of the firm. The authors argue that expanded trading hours, as well as lower transaction costs due to price competition among the exchanges, attract more informed traders, which ensures that the stock price more closely follows its intrinsic value. Generally, expanded trading hours are expected to reduce pricing errors and decrease the volatility of the opening prices, according to Lowengrub and Melvin (2002) and Yamori (1998). Furthermore, Chouinard and D'Souza (2004) show a narrowing of spreads on the domestic market after the listing, which can be explained by competition for order flow. Total trading volume is expected to rise after a cross-listing, but the effect on domestic trading volume is not as clear-cut. Smith and Sofianos (1997) and Foerster and Karolyi (1993) find increasing domestic trading volume, while Levine and Schmukler (2006) outline that trading volume migrates into the international equity market, leading to a decrease in domestic trade.

A dual listing improves a company's public relations. Baker et al. (2002) find that visibility increases significantly after cross-listing. Hendricks et al. (2010) find, for example, that local analysts are better at forecasting equity returns. In addition, stringent reporting and disclosure requirements increase the amount of publicly available information, leading to a lower cost of capital for cross-listed companies according to King and Mittoo (2007). Furthermore, cross-listings can be used for marketing purposes, might be part of a company's internationalization strategy, and can be used to signal that a company is now a global player, as Laakso (1993) stresses. Crosslistings convey the message that the company's management is confident about the company's future prospects. Approval by the regulatory authorities and admission of the security to the respective market confirms the managers' forecasts.

Companies are required to adhere to local corporate governance practices after listing on a stock exchange. Doidge et al. (2004), as well as King and Segal (2003), show that cross-listings in countries with strict disclosure requirements and investor protection have an especially positive effect on a firm's valuation.

High transaction costs, legal provisions, taxes, or lack of available information can lead to segmented markets that prevent investors from buying a certain security. Stapleton and Subrahmayan (1977) show that cross-listing is a way to circumvent this problem. This leads, according to Mittoo (1992) and King and Mittoo (2007), to a broader shareholder base, which is accompanied by lower required returns and thus a higher valuation. Furthermore, it complicates hostile takeovers. However, according to Hannich et al. (2005), it is uncertain whether a cross-listing significantly increases foreign ownership since the percentage holding of foreign investors in German companies is not substantially different between companies that pursue an international cross-listing strategy and those that do not. 
Burns (2004) shows cost advantages for cross-listed foreign acquirers in crossborder take-over situations when they use locally traded equity. Additionally, presence on the stock market prior to a merger or an acquisition raises awareness and acceptance of the company and increases investor confidence, which then augments the chances that any tender offer will be accepted, according to Brown (2000). Hannich et al. (2005) stress that the acquisition process can occur more quickly after cross-listing. Löwe (1998) points out that locally traded shares can also be used in employee stock programs.

\subsection{Disadvantages of cross-listings}

In general, a company incurs an initial listing fee and a continuing registration fee depending on the number of shares listed and traded on an exchange. Table 1 compares these direct costs for listing and maintaining the listing on the three markets analyzed in this article. The fees for cross-listing differ substantially among exchanges, with a general tendency being that the bigger the market in terms of market capitalization, the higher the direct costs of being listed on it.

Hannich et al. (2005) point out that there are indirect costs of cross-listing that are generally higher than the direct costs. These consist of compliance costs and related follow-up costs. Disclosure requirements can be substantial since financial statements have to be restated according to local accounting principles and standards. Financial and legal advice is required to achieve access to the foreign market and ensure that the company complies with all laws and regulations. The risk of exposure to lawsuits in a foreign country, with all the accompanying damages, is seen as a further disadvantage. Moreover, companies are required to install a local investor relations program, which includes preparing annual and other reports, holding press conferences, and so forth. Laakso (1993) and Chouinard and D'Souza (2004) stress that companies have to make arrangements for clearing and settlement of the trades in the country where they will be listed. Because of their fixed nature, these costs

Table 1 Overview of listing costs

\begin{tabular}{llll}
\hline & SIX $^{\mathrm{a}}$ & Deutsche Börse & TSE \\
\hline \multirow{2}{*}{ Initial listing } & Flat charge & Admission & Examination Fee \\
& CHF 5,000 & EUR 3,000 (CHF 4,472) & JPY 2 mm (CHF 23,482) \\
& & Initial Listing Fee & Initial Listing Fee \\
Annual fees & EUR 2,500 (CHF 3,727) & JPY 2.5 mm (CHF 29,352) \\
& No annual fees & Prime Standard & JPY 0.12-JPY 0.84 mm \\
& & EUR 10,000 (CHF 14,906) & (CHF 1,409-CHF 9,862) \\
& & General Standard & \\
& & EUR 7,500 (CHF 11,180) & \\
\hline
\end{tabular}

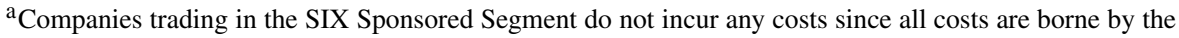
sponsoring securities dealer

${ }^{b}$ Listing costs for the regulated market. Exchange rates as of 01/01/2009. Source: SIX (2007), Deutsche Börse (2008), and TSE (2007)
} 
often prevent small- and midcap companies from cross-listings, according to Pagano et al. (2002). Lastly, according to Hannich et al. (2005), the delisting process itself can become burdensome due to market-exit barriers.

\section{Data}

We use data from three major equity markets: the SIX (1998-2008), Deutsche Börse (2001-2008), and the TSE (1997-2008).

Table 2 compares the characteristics of these markets. The choice of these three markets is justified, first, by their size. According to WFE (2008), all three markets rank among the biggest exchanges globally and jointly make up $12.6 \%$ of the global market capitalization, while the number of listed companies amounts to $7.8 \%$ of all listings globally. Second, all three markets recently experienced a considerable decrease of foreign listings, which provides a comprehensive sample to examine delistings in a cross-country context-with exchanges located in several countries and companies from various countries. The decrease in foreign listings is not an exchange-specific phenomenon but a global trend: the share of companies with a listing on a foreign market fell from 13.4\% to 7.0\% between 1997 and 2007. Last, the different characteristics of the three markets allow drawing further conclusions by comparing and contrasting the results of the empirical study. The different time horizons for the analysis are due to restrictions in data availability.

Despite their size, the US markets are not included in this study. NYSE cannot be included since it does not collect or provide any data about delistings. Even though NASDAQ does provide this type of data, this exchange is not included because the vast majority of companies delisted from it are still traded publicly on the US OTC markets. This continued trading precludes any meaningful analysis. London Stock Exchange cannot be included due to a lack of data about delistings. The pan-European stock exchanges-OMX and Euronext-were not included due to the small size of the individual markets. Furthermore, the number of delistings from them is very low.

The overall sample consists of 255 companies that delisted from SIX, its Sponsored Segment, Deutsche Börse, or TSE. To be included in the sample, the companies needed to have an identifiable announcement and delisting date. In addition, we

Table 2 Characteristics of the markets investigated

\begin{tabular}{llll}
\hline & SIX & Deutsche Börse & TSE \\
\hline Market Capitalization (in CHF bn) & 1,439 & 2,386 & 4,868 \\
Rank (in Terms of Size) & 15 & 9 & 2 \\
Listed Companies & 341 & 866 & 2,414 \\
Foreign Listed Companies & 81 & 105 & 16 \\
Share of Foreign Companies & $25 \%$ & $12 \%$ & $1 \%$ \\
\hline
\end{tabular}

Data as of 12/31/2007. Source: SIX (2008) and WFE (2008) 
required that data on the underlying stock (i.e., prices and trading volume on its primary exchange) is available from at least 280 trading days before the announcement until at least 20 trading days after the delisting.

Daily closing prices denominated in local currency from the primary exchange are used to calculate daily total returns. Daily share turnover on the companies' primary exchanges are used to examine the volume effects. All data is adjusted for corporate events.

The data sample for the SIX Swiss Exchange consists of 72 companies that delisted between January 1998 and September 2008. SIX provided the data about all delistings in the above-mentioned period. ${ }^{1}$ Subsequently, ordinary delistings were removed. As announcement date, we use the date SIX officially published the delisting on its homepage. Initially, 88 companies were identified as having delisted from SIX while remaining listed on another exchange. Out of these 88 companies, 31 were subsequently traded in the Sponsored Segment, which was installed on July 1, 2005. The trading of 16 companies resumed immediately in the Sponsored Segment after they had delisted from SIX and these 16 were therefore excluded from the sample. The trading of the other 15 companies stopped completely for at least 20 days before resuming trade in the Sponsored Segment and, therefore, were retained in the sample.

The sample SIX Sponsored Segment contains 73 companies. The Sponsored Segment was cancelled on November 21, 2008. By regulation, the companies listed in this segment do not have their primary listing on SIX. Therefore, this cancellation can be viewed as a delisting of a secondary listing. SIX officially announced the cancellation on October 31, 2008. This date was used as the announcement date for the entire sample.

The sample from Germany consists of 65 companies. The sample is based on an overview of all foreign delistings in Germany between 2001 and 2008 provided by Hoppenstedt Aktienführer. Subsequently, Bloomberg was used to find the announcement date as well as the effective delisting date. After removing merged, acquired, or bankrupt companies, the data from Hoppenstedt Aktienführer indicated 131 delistings of foreign companies. However, it was not possible to reconcile the data of the delisting of 66 companies with Bloomberg so these 66 were excluded, which reduced the sample to 65 companies. Nevertheless, the sample for Germany is comprehensive enough to be included in this study.

The sample from the TSE comprises 45 companies. It is constructed using an overview of all listings and delistings of foreign companies between 1973 and 2008 provided by TSE. Bloomberg was used to find the corresponding announcement dates. It was possible to reconcile all delistings between 1997 and 2008 with Bloomberg. The sample is restricted to this period, since Bloomberg does not provide detailed information on corporate action prior to 1997.

We use indices to approximate return and transaction volume of the market. Data availability imposes restrictions on the index choice. Specifically, there is transaction volume missing for broad-based indices (for the entire period under observation), which leads to the use of narrower (often blue-chip) indices. Since there is generally

\footnotetext{
${ }^{1}$ We thank SIX, especially Patricia Cruchon, for providing this data.
} 
a very high correlation between indices from one country, effects due to index choice are not expected to be material. For consistency reasons, the same indices are used to estimate the return and trading volume of certain markets. ${ }^{2}$

\section{Methodology}

To analyze share prices and trading volume around the announcement of a delisting as well as around the effective delisting, we apply an event study methodology as outlined by Campbell et al. (1997).

In this paper, there are two event dates, the announcement date and the date of the effective delisting. The length of the period between the announcement and the delisting varies from case to case. The event window consists of 20 pre-event days as well as 20 post-event days plus the event day itself, totaling 41 days [ $-20,20]$. We choose 260 days $[-280,-21]$ as the estimation window before the announcement since we do not expect either the announcement or the delisting to significantly alter the determinants of normal performance. We apply the same parameters to analyze the effects of both events so as to avoid the situation where the first event (the announcement) lies within the estimation window for the second event (the delisting), and thus biases the parameters of the normal performance model. According to Peterson (1989), the length of our estimation and event window lies within the range typically used in other event studies.

Brown and Warner (1980, 1985), as well as Campbell et al. (1997), show that statistical significance is generally higher the shorter the event window. If the event date is precisely known, it is beneficial to shorten the event window as much as possible in order to increase the ability to statistically identify any effects. However, it is preferable to suffer weakened statistical power rather than miss the event or parts of the effect around the event entirely. Therefore, this study uses a rather long event window of 41 days. First, this takes account of the possibility that information was made public before the announcement date used in this study. Second, such a long window allows capturing the whole effect of a delisting if the markets do not adjust immediately to the new information or situation. Third, it takes into consideration the fact that dissemination of company-specific information may occur over a period of several days. We overcome the disadvantages associated with a very long event window by analyzing a subsample of data out of the whole event window.

\subsection{Analysis of abnormal returns and volumes}

We use continuously compounded returns throughout the analysis. To determine an event's impact on security prices, we calculate abnormal returns (AR) as the deviations from expected returns. We use the market model to calculate the expected returns of the stocks, applied to a company's primary (domestic) market. Dyckman et al. (1984) show that in case of uncertainty about the event date, the use of the market model is beneficial. The model's parameters are calibrated during the estimation

\footnotetext{
${ }^{2} \mathrm{~A}$ list of the 20 market indices used is available from the authors upon request.
} 
window mentioned above. We expect that the majority of a firm's trading is concentrated on its domestic market. Therefore, the domestic market should have the biggest influence on a security's price. To draw conclusions about the event of interest, we first calculate average abnormal returns across stocks and, finally, cumulative average abnormal returns (CAR) across time.

Analysis of abnormal transaction volume is very similar to analysis of abnormal returns and described in detail in for example Wilkens and Wimschulte (2005). We focus on the number of shares traded daily as a measure for transaction volume and concentrate on the transaction volume on a company's primary market.

The distribution of trading volume is positively skewed and departs significantly from normality. Therefore, daily trading volume must be log-transformed first in order to yield a more symmetric distribution. A constant is added to the actual trading volume to obtain a well-defined function even in the case of no trading activity in one period. Given the generally high trading volumes, adding a small constant to the actual volume should not affect the distributional properties significantly, according to Ajinkya and Jain (1989).

$$
V_{i, t}=\ln \left(1+V_{i, t}^{*}\right)
$$

where $V_{i, t}$ is the log-transformed period- $t$ trading volume of security $i ; V_{i, t}^{*}$ is the period- $t$ trading volume of security $i$.

We compare actual transaction volumes to a benchmark volume calculated with a market model for trading volumes according to Ajinkya and Jain (1989). Even though there is no theoretical foundation for this sort of volume analysis, several papers encourage the use of a model that relates a security's trading volume to the trading volume of the entire market by linking the trading volume to information releases. Moreover, Ajinkya and Jain (1989) mention that use of a market model for trading volume can be justified by assuming a multivariate normal distribution for the crosssection of securities, which is an appropriate assumption for log-transformed volume measures.

After generating the normal transaction volume for an individual security, the steps in analyzing abnormal transaction volumes are the same as for abnormal returns. First, we subtract the normal volume from the actual trading volume in order to derive the abnormal transaction volumes (AV). To detect any abnormalities from the event under observation, we aggregate the abnormal trading volumes across securities and across time to obtain the cumulative average abnormal volume (CAV).

\subsection{Significance tests}

The null hypothesis is that the event does not have any influence on return or volume.

$\mathrm{H}_{0}$ : Return and volume in the event period equal their expected value and, therefore, (cumulative) average abnormal returns/volumes are zero.

The significance of abnormal returns is first tested with a parametric Student t-test according to the approach outlined in Brown and Warner (1985). This standard t-test takes the cross-sectional dependence in the security-specific excess returns into account by estimating the variance of the AR from the time series of abnormal returns 
occurring during the estimation period. Ignoring positive cross-sectional dependence would result in a variance estimation that is systematically too low, implying too many rejections of the null hypothesis. However, an adjustment for cross-sectional dependence is not always necessary. In the case of a small degree of dependence, ignoring it would lead to only a small bias in the variance estimation. However, in the case of independence, such an adjustment for dependence can even be harmful, as stressed by Brown and Warner (1985). Therefore, they propose an alternative test that standardizes each abnormal return by its estimated standard deviation. This test assumes cross-sectional independence and thus proves superior under certain conditions. However, Campbell et al. (1997) argue that the results of these two test specifications are mostly very similar since the variances of the abnormal returns are frequently of similar magnitude across securities.

Generally, many statistical problems can arise in the event study methodologyespecially in the testing of statistical significance. Brown and Warner (1985) prove that using the market model and applying such a standard parametric test accommodates a wide variety of special conditions while remaining well specified. The benefits of incorporating advanced techniques are only minimal and sometimes apply only to special cases. Binder (1998) concludes, therefore, that many of the problems arising in statistical tests are minor in practice and can be ignored.

To overcome any shortcomings stemming from wrong assumptions about the distribution of abnormal returns, we apply in addition a nonparametric test, namely, the rank test proposed by Corrado (1989). Another common nonparametric test-the sign test-is not applied in this study since it requires abnormal returns to have a symmetrical distribution; the rank test does not and thus this test is not influenced by the skewness of abnormal returns.

\section{Empirical results: price and volume effects}

First, we present price and volume effects around the announcement as well as around the delisting for the full sample. Subsequently, we analyze the same effects in each of the subsamples (i.e., SIX, SIX Sponsored Segment, Deutsche Börse, and TSE).

\subsection{Full sample}

Figures 1 and 2, along with Table 3, give the results for the full sample. Figure 1, panel (a) shows the development of the CAR over the entire event window around the announcement. Hardly any price effects are registered across the entire period of 41 trading days and the CAR amounts to only $0.27 \%$, which is statistically insignificant. It seems that the announcement itself is accompanied by negative effects on the valuation. All ARs are negative during the 3 days around the announcement and the AR is insignificantly negative at $-0.15 \%$ on the announcement day itself. Analyzing the development of CAR over the event window, we notice a slight but gradual increase prior to the event, which is offset by a decline around the announcement. The CAR reaches its minimum of $-0.72 \%$ on $t=13$, before the valuation picks up again during the last days in the event window.

In contrast to the return development around the announcement, there does appear to be a trend in the pre-event period, before the delisting as illustrated in Fig. 1, 

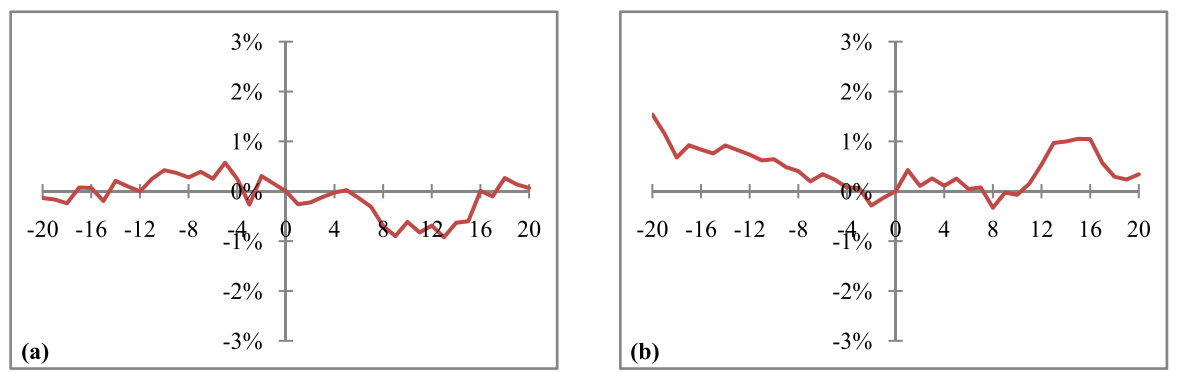

Fig. 1 Price effects around announcement and delisting. Cumulative average abnormal returns in the 41 days $[-20,20]$ relative to the event date $(t=0)$. Panel (a) shows effects around the announcement date, panel $(\mathbf{b})$ around the delisting date based on the full sample $(n=255)$
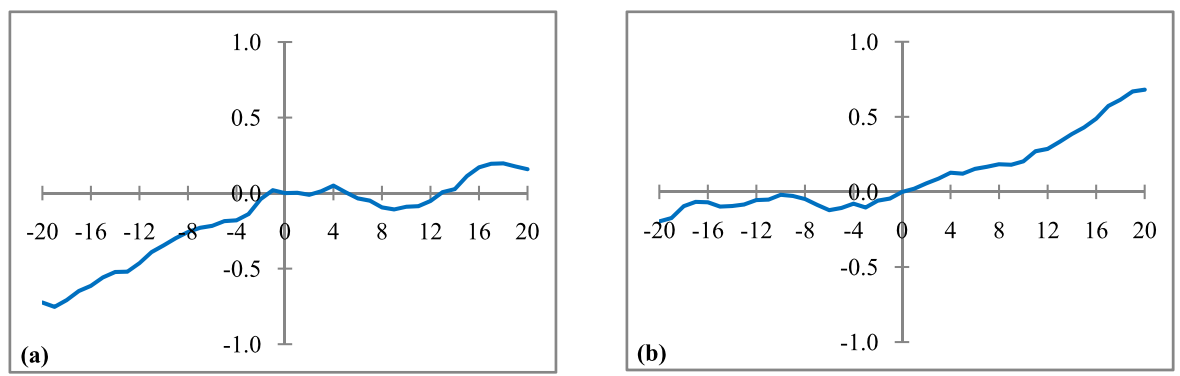

Fig. 2 Volume effects around announcement and delisting. Cumulative average abnormal volume in the 41 days $[-20,20]$ relative to the event date $(t=0)$. Panel (a) shows effects around the announcement date, panel (b) around the delisting date based on the full sample $(n=253)$

panel (b). Over the pre-event period, the CAR is significantly negative at $-1.49 \%$. The CAR remains negative over shorter pre-event periods, but is no longer significant. The initial decline in valuation is halted by positive ARs on the three days surrounding the delisting. A positive price effect, with AR of $0.13 \%$, is found on the day of the effective delisting. In the post-event period, the total sample experiences an insignificant gain in value, with a positive CAR of $0.34 \%$. Stock prices tend to fall during the 41 days around the delisting and the CAR is $-1.02 \%$ over the whole event window.

Figure 2, panel (a) shows CAV development of the total sample around the announcement date. Trading volume on the companies' primary exchanges increases prior to the announcement of a delisting. All pre-event subperiods show positive CAVs at the $1 \%$ significance level. The AVs cumulate to 0.79 over the whole preevent period. This increase seems to be slowed by the announcement. All in all, the CAV increases only slightly, by 0.16 , during the post-event period. The CAV over the entire event window is 0.93 and significant at the $1 \%$ level.

The CAV around the delisting is depicted in Fig. 2, panel (b). Over the predelisting period, the CAV tends to move sideways - in contrast to the increase prior to the announcement. In the post-event period, however, the AVs are predominantly positive; thus, the CAV increases steadily and the subperiods following delisting eventually show significance. The CAV amounts to 0.68 over the entire post-event period, which is significant at the $1 \%$ level. Over the whole event window, the results are 


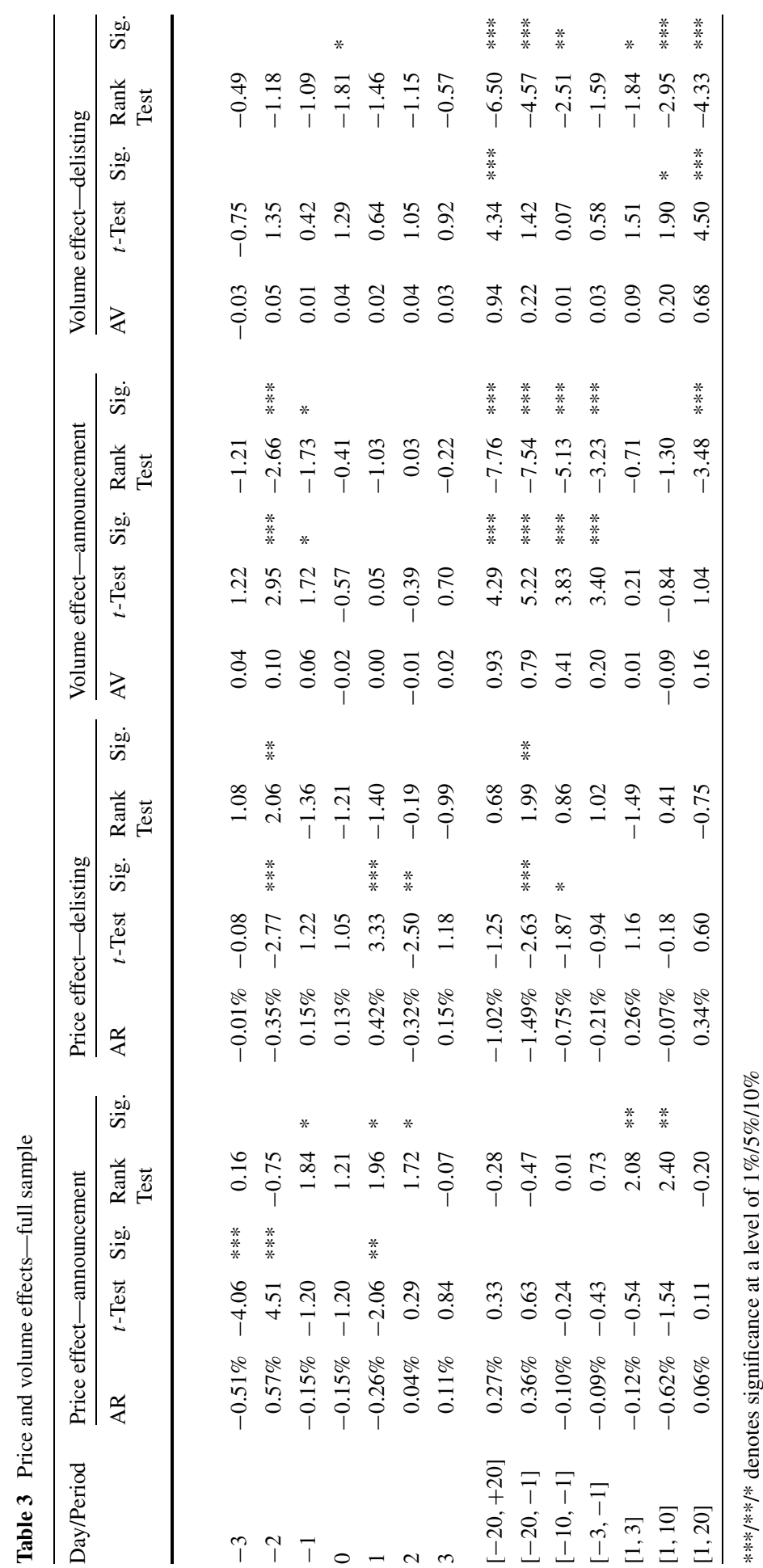


similar to the ones found around the announcement and the CAV is 0.94, which is significant at the $1 \%$ level and implies an increase in trading volume on the companies' primary exchange-mainly induced by a shift in trading volume that occurred after the delisting. The period around the announcement can be characterized by positive AVs, which can be seen as the starting point for the increase in trading volume on the companies' primary exchanges following the delisting.

\subsection{Subsample-SIX Swiss Exchange}

Figures 3 and 4, along with Table 4, set out the results for the SIX. The CAR increases considerably-yet insignificantly-by $2.24 \%$ over the whole event window around the announcement, as shown in Fig. 3, panel (a). During the pre-event period, the CAR amounts to $1.36 \%$; it is $1.17 \%$ over the period following the event. Despite the overall positive effects, there is a negative price effect in the five days around the announcement but only on $t=1$ is this effect statistically significant.

The announcement effect over the entire event period is positive for this subsample; however, the opposite occurs around the delistings at the SIX, as can be seen in Fig. 3, panel (b). There is an insignificant negative CAR of $-2.05 \%$ over the whole event window. It is important to note that the negative price effect in the post-event
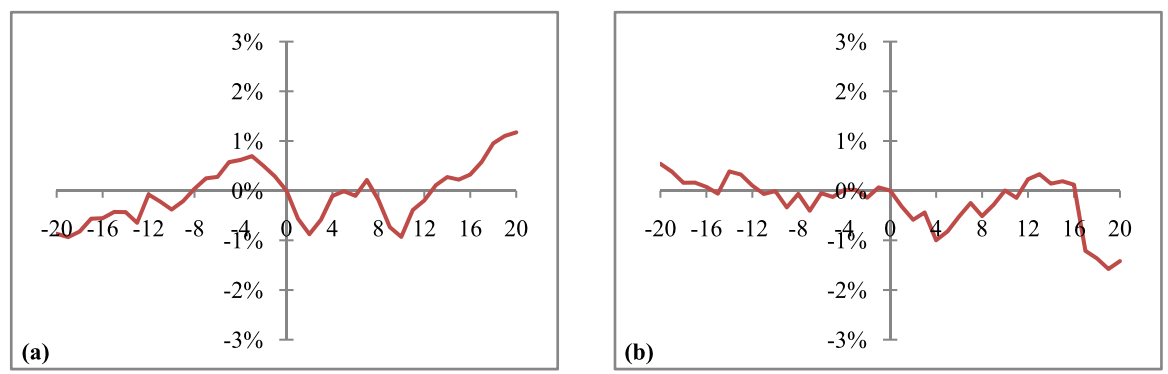

Fig. 3 Price effects around announcement and delisting-SIX Swiss Exchange. Cumulative average abnormal returns in the 41 days $[-20,20]$ relative to the event date $(t=0)$. Panel (a) shows effects around the announcement date, panel (b) around the delisting date based on the subsample of the SIX $(n=72)$
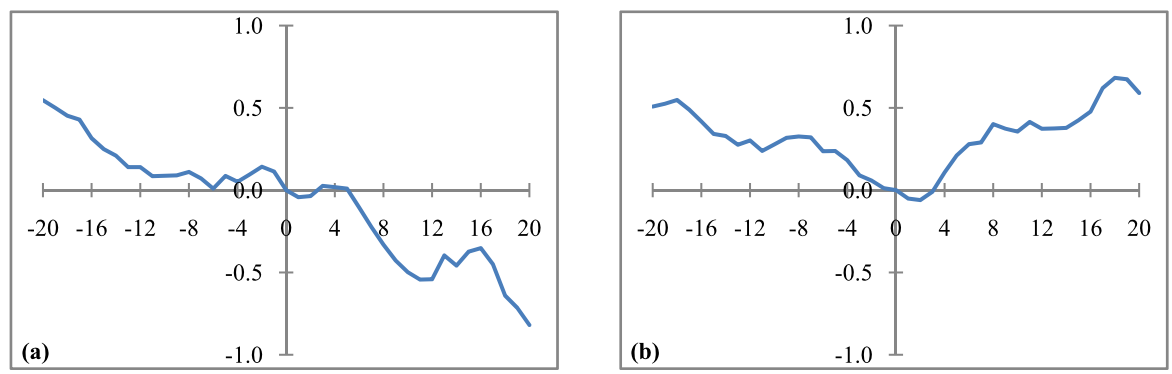

Fig. 4 Volume effects around announcement and delisting-SIX Swiss Exchange. Cumulative average abnormal volume in the 41 days $[-20,20]$ relative to the event date $(t=0)$. Panel (a) shows effects around the announcement date, panel (b) around the delisting date based on the subsample of the SIX $(n=71)$ 


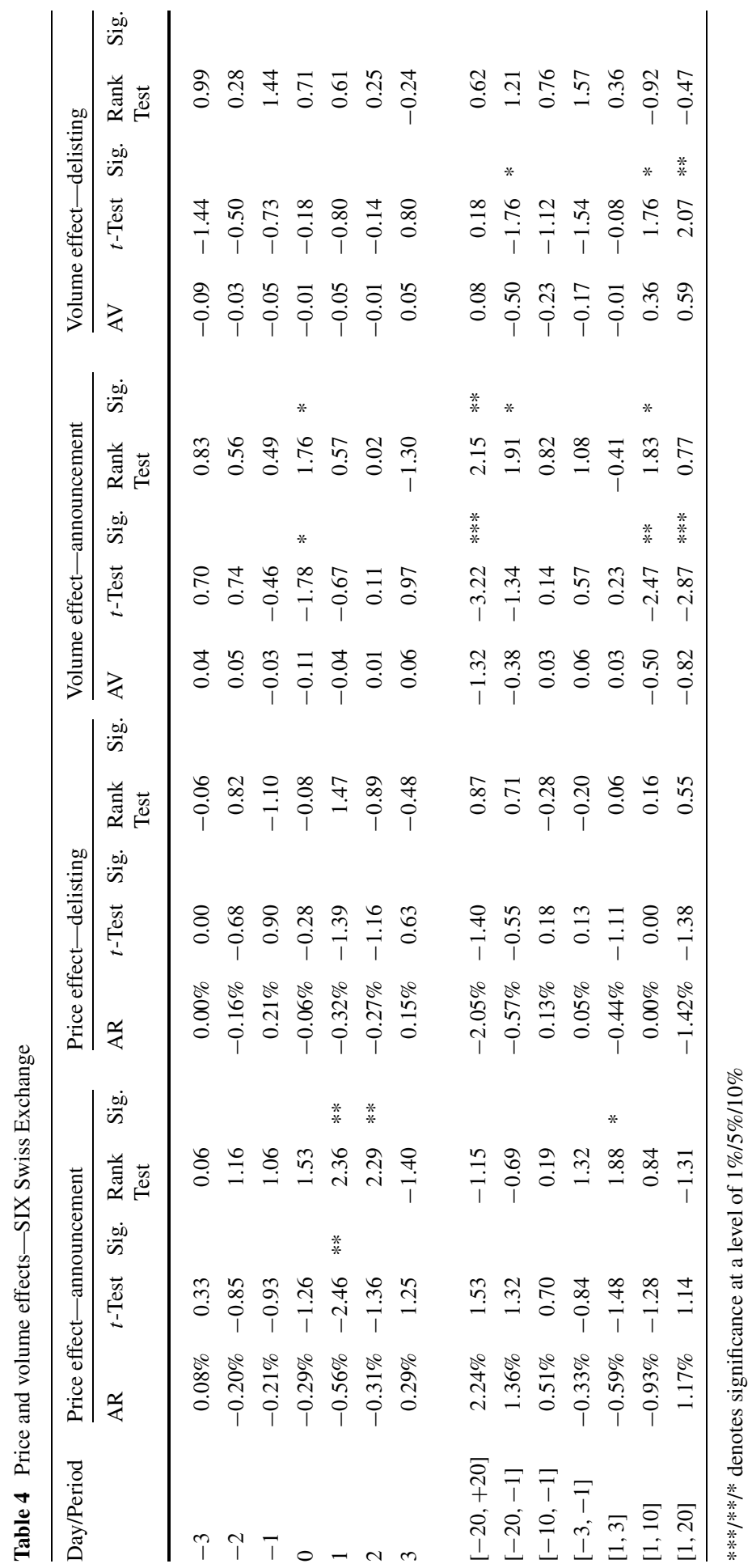


period is mainly due to the sharp decline after $t=16$. These strong negative returns in the late post-event period lead to a severe fall in CAR that cannot be explained by the delisting. We thus conclude that the actual delisting from SIX does not have much of an effect on the firm's valuation.

Figure 4, panel (a) illustrates the volume effects around the announcement of a delisting from SIX; panel (b) shows these effects around the delisting itself. Remarkably, the results deviate substantially from those for the total sample. Generally, the volume effects in the subsample SIX are rather weak. The AVs around the announcement are predominantly negative during the entire event window, which results in a CAV of -1.32 over the event window. The decline in trading volume in the postevent window of -0.82 is much more severe than the -0.38 decline in the pre-event window.

The pattern of trading volume over the entire event window around the delisting shown in Fig. 4, panel (b) is sharply different from the pattern around the announcement. Furthermore, it contradicts to some extent the results shown for the total sample. The development of CAV in the pre-event period is negative $(-0.50)$, which means that the domestic exchange lost trading volume. The major difference, however, occurs around the event date since the sign of the AV changes within the event window. CAV thus has a minimum occurring on $t=2$. The pre-event CAV is -0.50 , while the post-event CAV is 0.59 . These results indicate that the domestic market loses transaction volume until the delisting and then starts to regain order flow. This can be explained by migration, which means that a part of the transaction volume the foreign market was able to capture is flowing back into the companies' primary/domestic market after the delisting. This effect, which occurs after the delisting, reverses the initial decline and volume on the domestic exchange remains nearly stable over the entire event period.

\subsection{Subsample-SIX Sponsored Segment}

Since turnover in the SIX Sponsored Segment was always small and a company incurs no costs for this access to the Swiss capital market we do not expect significant effects of delisting in this subsample.

The price effects around the announcement and around the cancellation of trading in the Sponsored Segment do not exhibit any specific pattern (see Fig. 5 and Table 5). This is due to heavily fluctuating ARs during the entire event windows. On the whole, announcement of the cancellation in Fig. 5, panel (a) is accompanied by negative effects on the companies' valuation. The CAR in the event period amounts to $-1.20 \%$, which is the most negative value across all subsamples, but still not significant. The AR on the announcement day itself is $-0.23 \%$.

The CAR shows a falling tendency over the period prior to the delisting (see Fig. 5, panel (b)), but there is a compensating trend following the event. Hence, the patternof the ARs around the delisting generally confirms the pattern for the full sample. The decline in the pre-event subperiods is severe, but only significant according to the t-test. The ARs add up to $-2.96 \%$ over the 20 days prior to the delisting. This decline cannot be compensated by the sharp increase around the delisting. The AR of $0.64 \%$ on the event day is followed by an increase during the post-event period of $1.09 \%$, resulting in a CAR over the entire period of $-1.24 \%$. 


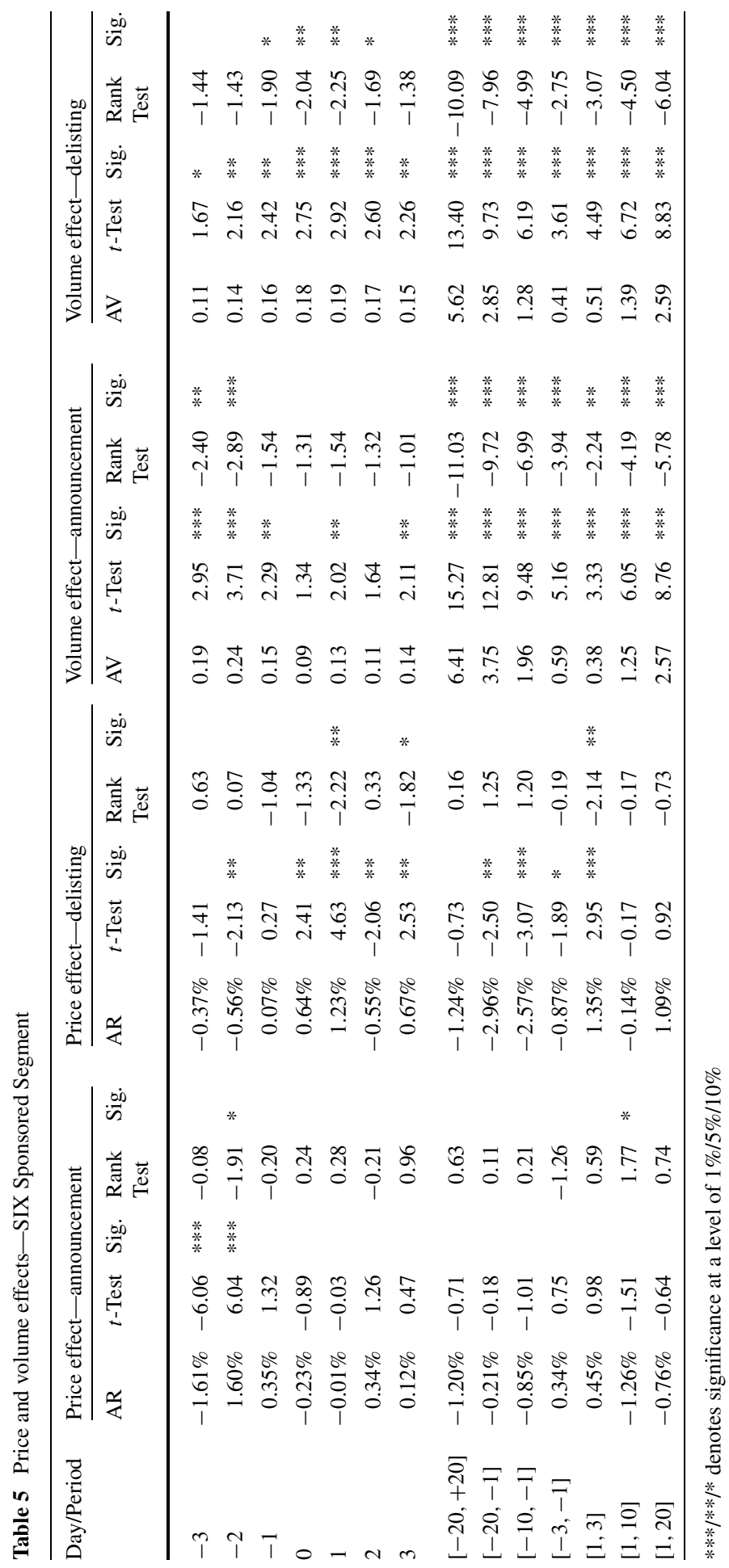



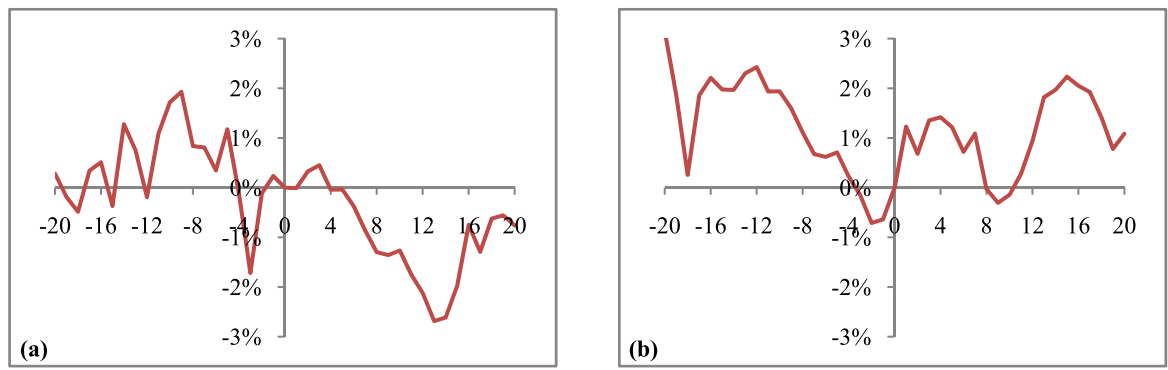

Fig. 5 Price effects around announcement and delisting-SIX Sponsored Segment. Cumulative average abnormal returns in the 41 days $[-20,20]$ relative to the event date $(t=0)$. Panel (a) shows effects around the announcement date, panel (b) around the delisting date based on the subsample of the SIX Sponsored Segment $(n=73)$
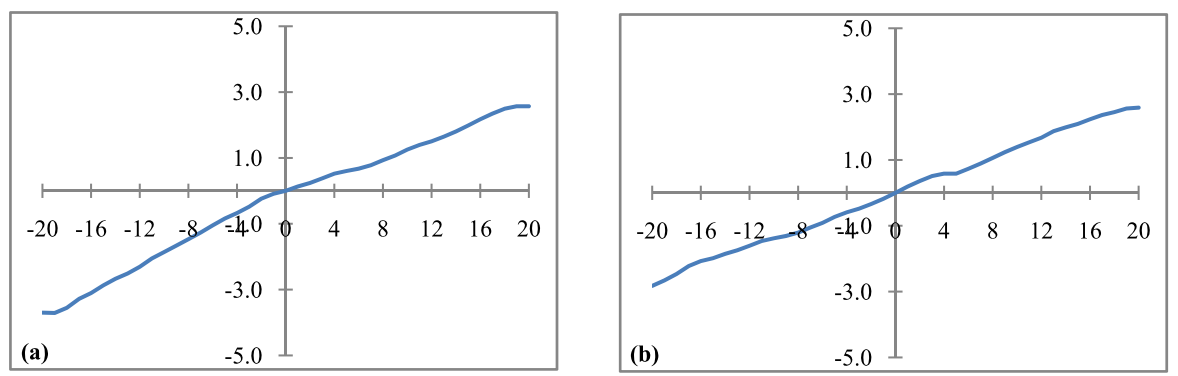

Fig. 6 Volume effects around announcement and delisting-SIX Sponsored Segment. Cumulative average abnormal volume in the 41 days $[-20,20]$ relative to the event date $(t=0)$. Panel (a) shows effects around the announcement date, panel (b) around the delisting date based on the subsample of the SIX Sponsored Segment $(n=73)$

The CAVs around announcement and delisting in Fig. 6 look almost the same. There seems to be no response to any of the events, neither positive nor negative. The behavior of the AVs is consistent across both events. During the whole event window, AVs are positive and their value remains nearly stable. This leads to (statistically significant) positive CAVs in nearly all subperiods.

\subsection{Subsample-Deutsche Börse}

The results for the German stock market, shown in Figs. 7 and 8 as well as in Table 6, reveal only weak effects. Initially, the CAR in Fig. 7, panel (a) is falling slightly by an insignificant $-0.21 \%$ over the pre-event period, but this decline is followed by an insignificantly positive CAR of $0.41 \%$ in the post-event period. In fact, the CAR moves sideward over the whole event period except on the days surrounding the announcement. There is a pronounced negative reaction to the announcement itself.

The effects over the entire event window around the effective delisting (see Fig. 7, panel (b)) are again weak and the CAR shows only a slight increase of $0.09 \%$ similar to the development around the announcement. However, a more detailed analysis reveals that the valuation declines steadily in the pre-event period and ARs add up to $-1.31 \%$. The valuation drops further on the event day before. After an ini- 


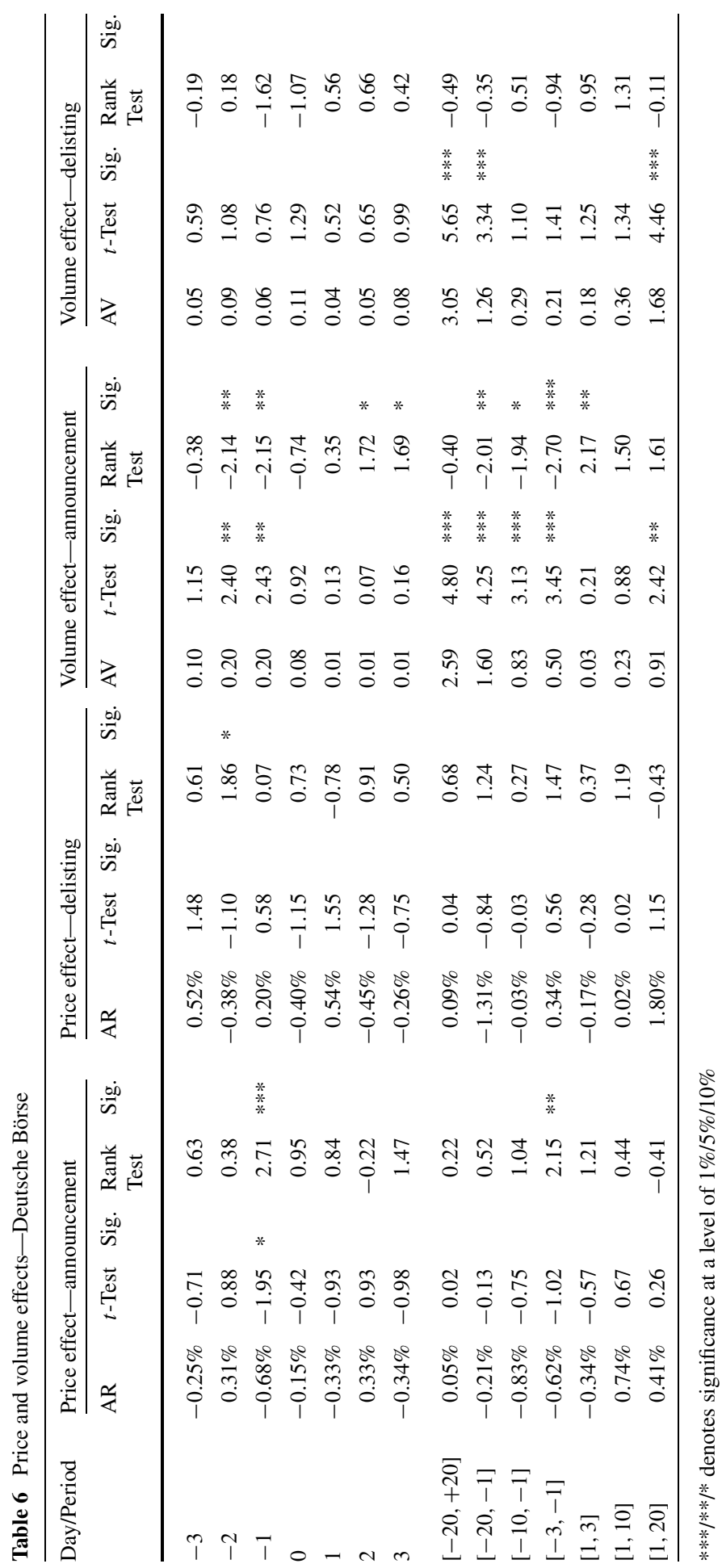



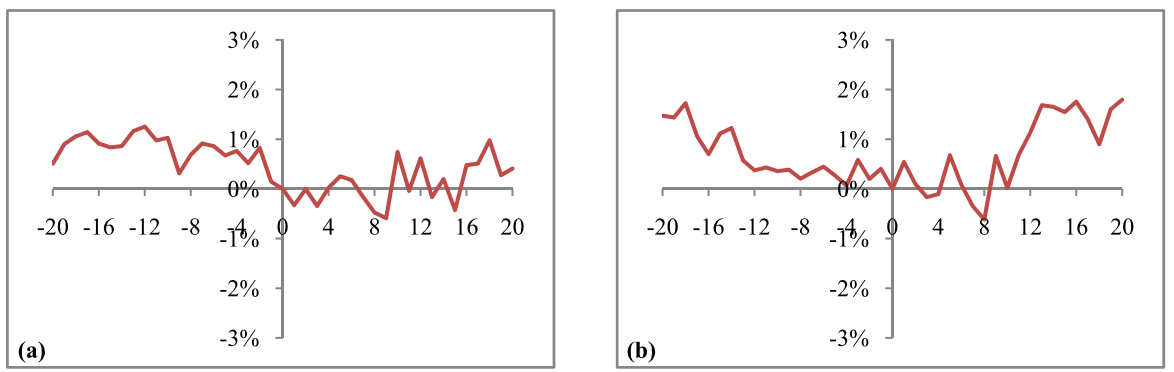

Fig. 7 Price effects around announcement and delisting-Deutsche Börse. Cumulative average abnormal returns in the 41 days $[-20,20]$ relative to the event date $(t=0)$. Panel (a) shows effects around the announcement date, panel (b) around the delisting date based on the subsample of the Deutsche Börse $(n=65)$
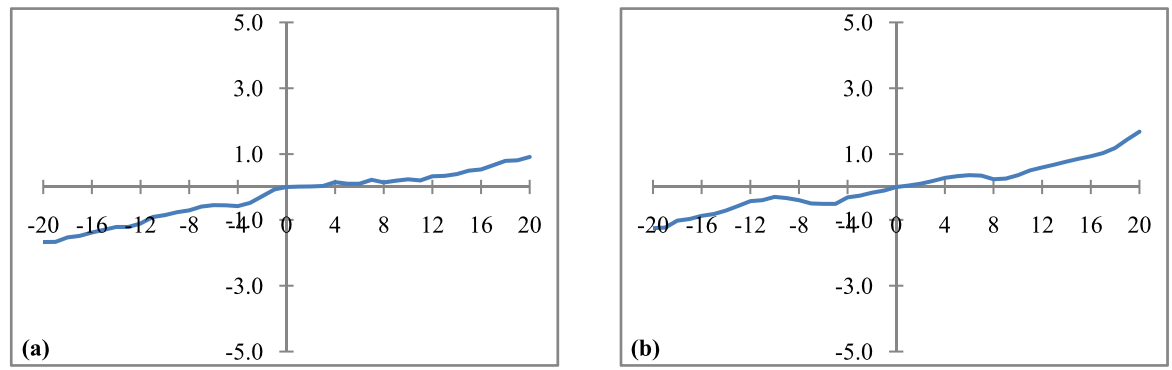

Fig. 8 Volume effects around announcement and delisting-Deutsche Börse. Cumulative average abnormal volume in the 41 days $[-20,20]$ relative to the event date $(t=0)$. Panel (a) shows effects around the announcement date, panel (b) around the delisting date based on the subsample of the Deutsche Börse $(n=64)$

tial lateral shift in the immediate post-event period of approximately 10 days, a peak in valuation occurs, which is mainly induced by the positive ARs after $t=10$ leading to a CAR over the entire post-event period of $1.80 \%$.

The volume effects illustrated in Fig. 8 show patterns similar to those observed in the SIX Sponsored Segment subsample. Once again, the effects around the announcement and the delisting are not substantially different. Furthermore, there is hardly any response to the events and AVs stay positive. This leads to a continuously rising CAV, which is halted temporarily by the announcement. Generally, the volume effects in this subsample are rather weak; not all subperiods show statistical significance.

\subsection{Subsample-Tokyo Stock Exchange}

We present the results for the TSE in Figs. 9 and 10 as well as in Table 7. The CAR in Fig. 9, panel (a) shows a similar pattern in the pre-event and the post-event period: negative ARs at the beginning of the pre-/post-event period are followed by positive ARs at the end of the corresponding period, resulting in a curved CAR line prior to and following the event. Therefore, the effects are strongest in the 10 days prior to the event (with a significant positive CAR of 1.22\%) and in the 10 days following the event (with an insignificant negative CAR of $-1.03 \%$ ). By extending these periods, the effects are partially reversed. All in all, the negative impacts on shareholder 


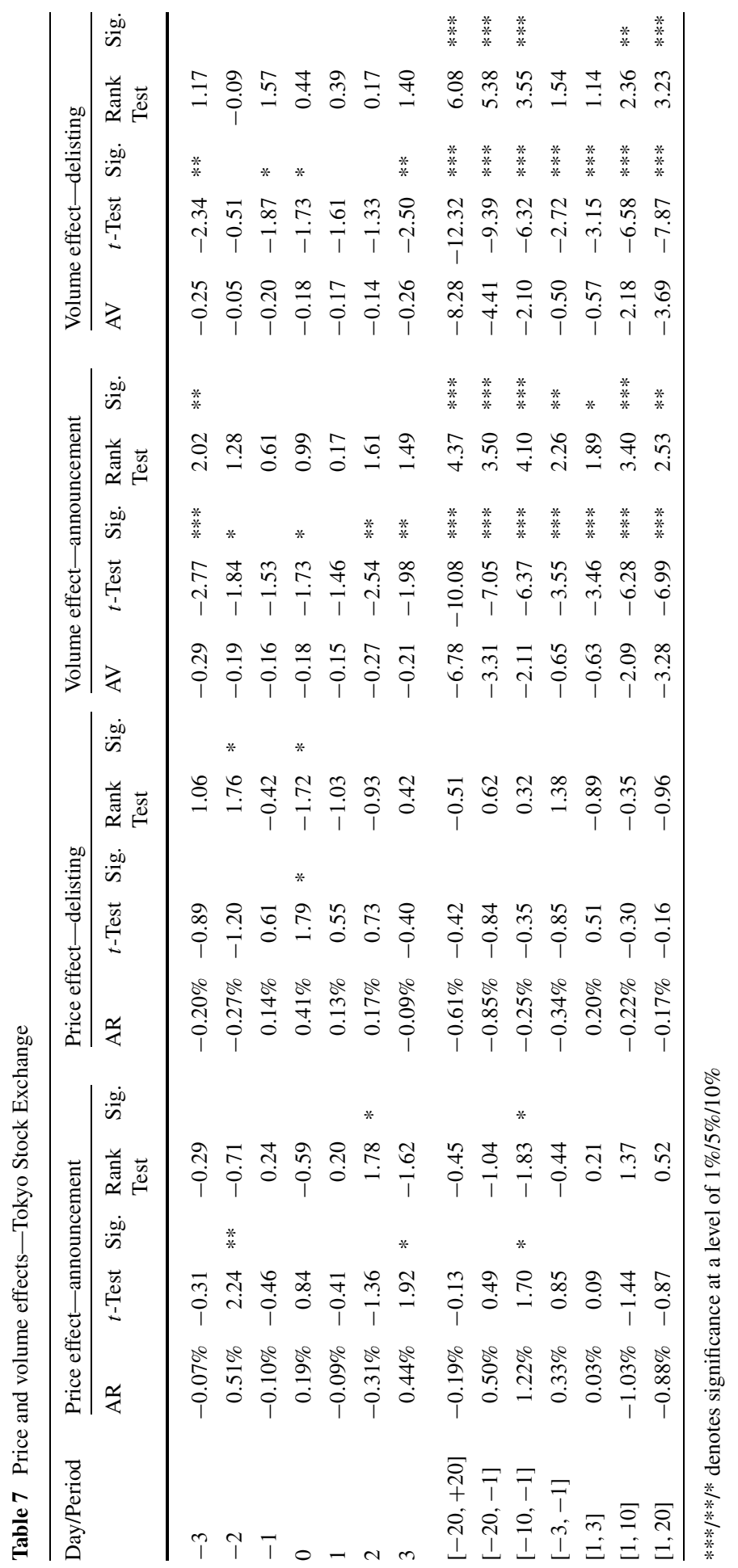



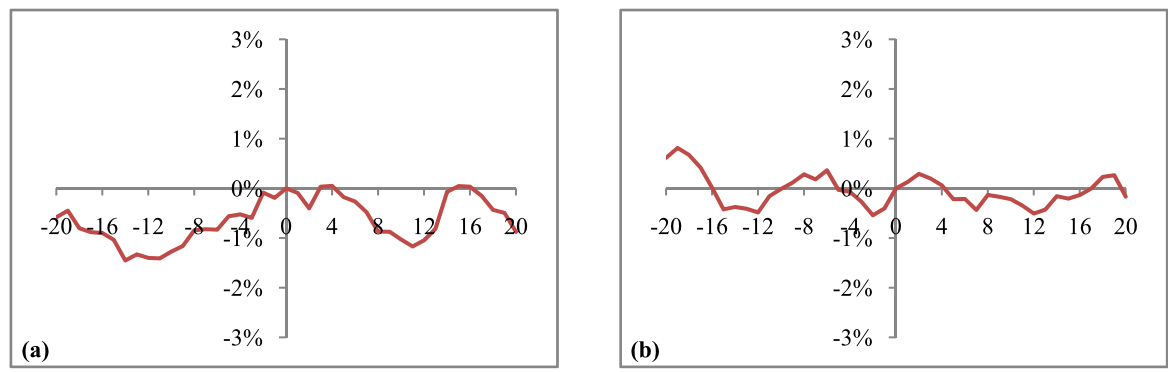

Fig. 9 Price effects around announcement and delisting-Tokyo Stock Exchange. Cumulative average abnormal returns in the 41 days $[-20,20]$ relative to the event date $(t=0)$. Panel (a) shows effects around the announcement date, panel (b) around the delisting date based on the subsample of the TSE $(n=45)$
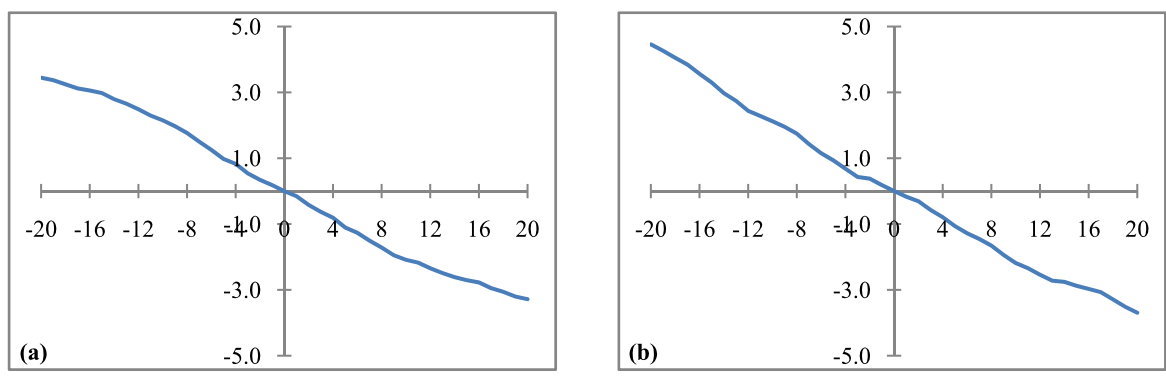

Fig. 10 Volume effects around announcement and delisting-Tokyo Stock Exchange. Cumulative average abnormal volume in the 41 days $[-20,20]$ relative to the event date $(t=0)$. Panel (a) shows effects around the announcement date, panel (b) around the delisting date based on the subsample of the TSE $(n=45)$

value prevail, with an insignificant CAR of $-0.19 \%$ over the entire event window. The positive AR on the announcement day as well as a pre-event run up during approximately 10 days before may be due to the special procedure for delistings of foreign companies from TSE. After receiving an application for a delisting, the security in question is designated as "Security under Supervision". In the following week, the TSE decides about the delisting and publishes an official announcement regarding the delisting. Therefore, the information about the delisting might become known before publication of the official announcement that was used as the announcement date in this study. Nevertheless, we capture a positive price effect even if we assume an earlier announcement since it would fall in the pre-event period that is characterized by increasing values. The valuation declines after the announcement, however, and thus brings the results closer to those of the other subsamples.

Delistings from TSE (see Fig. 9, panel (b)) appear to have no effect on security prices. The ARs show hardly any significance and the CAR gravitates around zero in all subperiods. Consequently, the CAR does not show any significance and adds up to $-0.61 \%$ over the whole event window. The delisting itself is accompanied and followed by positive price effects. The AR of $0.41 \%$ on the announcement day itself is significant at the $10 \%$ level according to both the t-test and the rank test.

TSE is the only market for which previous work examines the impact of voluntary delisting in an international context. Our results generally confirm the outcomes of the 
study by Ureche-Rangau and Carugati (2008), but those results are not in line with the findings of Das et al. (2004), who find a significant drop in valuation upon the announcement $(-6.0 \%$ over a 51-day event window) as well as around the effective delisting ( $-4.1 \%$ over a 51-day event window). However, the authors focus on U.S. companies only, which might explain the different results.

Volume in Fig. 10 shows a pattern comparable to that found for the other subsamples. AVs as well as CAV are strikingly consistent. However, in contrast to other subsamples as well as to the total sample, the CAV falls over the entire event window. Nevertheless, the constancy in AVs leads to the conclusion that neither of the events has an influence on trading volume on the companies' primary exchange.

\section{Conclusion}

In recent years, the international equity markets have experienced an increasing number of delistings of secondary listings. Companies are concentrating their listings, and thus canceling their secondary listings. We analyze the impact of delisting on the price as well as on the trading volume of a company's shares on its primary market by employing a standard event study methodology and taking into consideration the effects around the announcement as well as around the effective delisting.

The price effects are generally weak and only occasionally statistically significant. We find that development of CAR around the announcement is different in all subsamples and no obvious pattern is discernable. There seems to be no price reaction before the announcement, which is in line with market efficiency. The results also suggest that there have been no information leaks. On the days immediately around the announcement as well as in periods of up to 10 days following the delisting, we see a decline in value. However, these results are usually not significant and are offset by the end of the event window. One might thus conclude that market participants overreact to delisting news.

The price effects around the delisting are stronger but still insignificant. In the preevent period, delisting has a negative impact on security prices, suggesting that the markets are not efficient enough to capitalize all expected losses at the time of the announcement. The decline in value halts slightly prior to the delisting. Afterward, no general tendency is visible; however, a negative price effect over the entire event window occurs in most of the subsamples.

The development of volume around the announcement and the delisting shows many similarities to that of price. For the full sample, we observe an increase in volume on the company's primary exchange prior to the announcement as well as following the delisting. The increase following the delisting could be explained by migration of trading volume back to the domestic markets. On the subsample level, the delisting event does not appear to result in abnormal volumes.

Our results contradict earlier research to some extent. According to our results, managers should not be concerned that their decision to cross-list or not will materially and permanently impact the company's value. All price effects detected in this study are weak and most often reversed with time. However, our results do show that market reaction to delisting is heavily dependent on the individual situation of a company. Managers should be careful to compare the benefits realized by crosslisting with the related costs. 
Acknowledgements The authors thank Yakov Amihud, Alexander Kohler, Markus Schmid, and participants of the Topics in Finance 2009 workshop in St. Moritz as well as an anonymous referee for very helpful comments.

\section{References}

Ajinkya, B., Jain, P.: The behavior of daily stock market trading volume. J. Account. Econ. 11, 331-359 (1989)

Baker, H., Nofsinger, J., Weaver, D.: International cross-listing and visibility. J. Financ. Quant. Anal. 37, 495-521 (2002)

Basu, N.: Trends in corporate diversification. Financ. Mark. Portf. Manag. 24, 87-102 (2010)

Binder, J.J.: The event study methodology since 1969. Rev. Quant. Finance Account. 11, 111-137 (1998)

Brown, J.: Going from strength to strength. Euromoney December 2000, 98-100 (2000)

Brown, S., Warner, J.: Measuring security price performance. J. Financ. Econ. 8, 205-258 (1980)

Brown, S., Warner, J.: Using daily stock returns-the case of event studies. J. Financ. Econ. 14, 3-31 (1985)

Burns, N.: The role of cross-listed stock as an acquisition currency: evidence from takeovers of U.S. firms. Working Paper (2004)

Campbell, J., Lo, A., Mackinlay, C.: The Econometrics of Financial Markets. Princeton University Press, Princeton (1997)

Chouinard, E., D’Souza, C.: The rationale for cross-border listings. Bank Can. Rev. Winter 2003-2004, 23-30 (2004)

Corrado, C.: A nonparametric test for abnormal security-price performance in event studies. J. Financ. Econ. 23, 385-395 (1989)

Das, S., Saudagaran, S., Sinha, R.: An empirical examination of NYSE stocks voluntarily de-listing from the Tokyo stock exchange. Rev. Account. Finance 4(3), 47-72 (2004)

Deutsche Börse: Gebührenordnung für die Frankfurter Wertpapierbörse (2008). www.deutsche-boerse. com

Doidge, C., Karolyi, A., Stulz, R.: Why are foreign firms listed in the U.S. worth more? J. Financ. Econ. 71, 205-238 (2004)

Dyckman, T., Philbrick, D., Stephan, J.: A comparison of event study methodologies using daily stock returns: a simulation approach. J. Account. Res. 22, 1-30 (1984)

Foerster, S., Karolyi, A.: International listings of stocks: the case of Canada and the U.S. J. Int. Bus. Stud. 24, 763-784 (1993)

Hannich, F., Heinrich, T.A., Kachel, P., von Oppen, M.N.: Dual Listing-Eine ökonomische und juristische Analyse der Auslandnotierung deutscher Unternehmen. Studien des Deutschen Aktieninstituts, Frankfurt am Main (2005)

Hendricks, T., Kempa, B., Pierdzioch, C.: Do local analysts have an informational advantage in forecasting stock returns? Evidence from the German DAX30. Financ. Mark. Portf. Manag. 24, 137-158 (2010)

Karolyi, A.: Why do companies list shares abroad? A survey of the evidence and its managerial implications. Financ. Mark. Inst. Instrum. 7(1), 1-60 (1998)

Karolyi, A.: The world of cross-listings and cross-listings of the world: challenging conventional wisdom. Rev. Finance 10, 99-152 (2006)

King, M., Mittoo, U.: What companies need to know about international cross-listing. J. Appl. Corp. Finance 19(4), 60-74 (2007)

King, M., Segal, D.: Corporate governance, international cross-listing and home bias. Can. Invest. Rev. 16(4), 8-19 (2003)

Laakso, A.: Listing on Foreign Stock Exchanges. HSE Press, Helsinki (1993)

Levine, R., Schmukler, S.: Internationalization and stock market liquidity. Rev. Finance 10, 153-187 (2006)

Liu, S.: The impacts of involuntary foreign delistings: an empirical analysis. Working Paper (2004)

Löwe, C.: Motive für die Auflage von ADR-Programmen. In: von Rosen, R., Seifert, W. (eds.) Zugang zum US-Kapitalmarkt für deutsche Aktiengesellschaften, pp. 57-69. Studien des Deutschen Aktieninstituts, Frankfurt am Main (1998).

Lowengrub, P., Melvin, M.: Before and after international cross-listing: an intraday examination of volume and volatility. J. Int. Financ. Mark. Inst. Money 12(2), 139-155 (2002)

Merjos, A.: Stricken securities. Barron's Natl. Bus. Financ. Wkly. 43, 9 (1963) 
Mittoo, U.: Managerial perceptions of the net benefits of foreign listing: Canadian evidence. J. Int. Financ. Manag. Account. 4, 40-62 (1992)

Pagano, M., Röell, A., Zechner, J.: The geography of equity listing: why do companies list abroad? J. Finance 57, 2651-2694 (2002)

Peterson, P.: Event studies: a review of issues and methodology. Q. J. Bus. Econ. 28, 36-65 (1989)

Sanger, G., Peterson, J.: An empirical analysis of common stock delistings. J. Financ. Quant. Anal. 25, 261-272 (1990)

Smith, K., Sofianos, G.: The impact of an NYSE listing on the global trading of non-U.S. stocks. NYSE Working Paper 97-02, 1-54 (1997)

Stapleton, R., Subrahmayan, M.: Market imperfections, capital market equilibrium and corporate finance. J. Finance 32, 307-319 (1977)

Swiss Stock Exchange [SIX]: List of Charges (2007). www.six-swiss-exchange.com

Swiss Stock Exchange [SIX]: Annual Statistics (2008). www.six-swiss-exchange.com

Tokyo Stock Exchange [TSE]: Listing Guide for Foreign Companies (2007). www.tse.or.jp

Ureche-Rangau, L., Carugati, A.: Foreign delisting and domestic stock value: multiple frameworks, different views? In: Veit, D., Kundisch, D., Weitzel, T., Weinhardt, C., Rabhi, F., Rajola, F. (eds.) Enterprise Applications and Services in the Finance Industry, pp. 112-135. Springer, Berlin (2008)

Wilkens, S., Wimschulte, J.: Price and volume effects associated with 2003's major reorganization of German stock indices. Financ. Mark. Portf. Manag. 19, 61-98 (2005)

World Federation of Stock Exchanges [WFE]: Annual Statistics (2008). www.world-exchanges.org/ statistics/annual

Yamori, N.: Does international trading of stocks decrease pricing errors? Evidence from Japan. J. Int. Financ. Mark. Inst. Money 1998, 413-432 (1998)
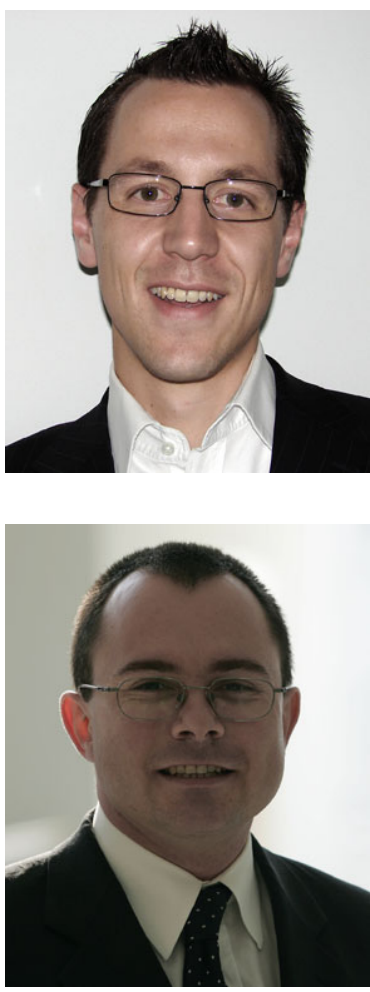

Matthias Pfister graduated from the University of St. Gallen with a Master's Degree in Banking and Finance and a CEMS Master in International Management. During his studies, he spent a semester at the Queen's University in Kingston (Canada) and at the Warsaw School of Economics in Warsaw (Poland). Currently he is working as an Analyst in the Investment Banking Division of Morgan Stanley in Zurich providing M\&A and capital markets advisory to primarily financial institutions and industrial clients.

Rico von Wyss is senior lecturer for finance at the Swiss Institute of Banking and Finance of the University of St. Gallen, Switzerland. His research interests include the empirical aspects of performance measurement, derivatives' pricing, international finance, and market microstructure, especially liquidity in financial markets. He serves as the executive director of the master's program in banking and finance and the Ph.D. program in management of the University of St. Gallen. Additionally, he is founder and board member of Algofin, a financial consulting company. 